\title{
TREATMENT OF METASTATIC HEAD AND NECK CANCER WITH MESENCHYMAL STEM CELLS COMBINED WITH PRODRUG GENE THERAPY
}

\author{
J. Lakota ${ }^{1,2, *}$, K. Gocarova ${ }^{3}$, S. Spanik ${ }^{3}$ \\ ${ }^{1}$ Laboratory of Molecular Oncology, Cancer Research Institute, Slovak Academy of Sciences, \\ Bratislava 83391, Slovakia \\ ${ }^{2}$ Center for Cell Therapy and Regenerative Medicine, St. Elizabeth Cancer Institute, Bratislava 81250, Slovakia \\ ${ }^{3}$ Department of Medical Oncology, St. Elizabeth Cancer Institute, Bratislava 81250, Slovakia
}

This is a clinical observation of a patient treated for metastatic head and neck cancer with mesenchymal stem cells mediated prodrug gene therapy. The cells were applied intravenously. We did not observe any therapeutic effect. However, a temporal bicytopenia was observed.

Key Words: metastatic head and neck cancer, therapeutic stem cells, blood counts.

A41 years old male patient with squamous carcinoma of the tongue (T2NOMO) refused any adjuvant chemotherapy after the surgery. He developed lung metastases 9 months after the second surgery for local relapse. After an approval of the Ministry of Health of the Slovak Republic, on day -2 he was admitted to the hospital. Infusion of Ancotil (2.5 g flucytosine/250 ml solution) started on day -1 bid 24 hours before the administration of therapeutic stem cells (TSC), and continued for 7 days. On day 0 the patient received $60 \times 10^{6}$ allogenic TSC intravenously. The therapeutic adipose tissue-derived mesenchymal stem cells were prepared as described previously [1]. There were no adverse effects during and 6 hafter the administration. 18 hours after the intravenous administration of the TSC, the patient developed fever $\left(39.0^{\circ} \mathrm{C}\right)$ with no signs of circulation instability. The fever resolved after antipyretics. There were no signs of any microbial infection. The following days the patient remained afebrile. Due to a sudden drop of white blood cells he received an oral antibacterial and antimycotic prophylaxis. On the day +6 he was discharged from the hospital with almost normalized blood counts. On day +18 during the outpatient control he was doing well. His blood counts (except mild anemia) were normal (Table). The CT scan performed on day +6 showed no difference in the size or density of his pulmonary metastases compared to the CT scan on day -1 . On the day +40 there were signs of a progression of the metastases on the CT scan.

Submitted: September 24, 2015.

${ }^{\star}$ Correspondence: E-mail: jan.lakota@savba.sk Abbreviation used: TSC - therapeutic stem cells.
Table. Blood counts of the patient during and after the therapy

\begin{tabular}{cccccc}
\hline Day & $\begin{array}{c}\text { Leukocytes } \\
\left(\times 10^{-12} / \mathrm{l}\right)\end{array}$ & $\begin{array}{c}\text { Neutrophils } \\
\left(\times 10^{-12} / \mathrm{l}\right)\end{array}$ & $\begin{array}{c}\text { Erythrocytes } \\
\left(\times 10^{-15} / \mathrm{l}\right)\end{array}$ & $\mathrm{Hb}(\mathrm{g} / \mathrm{l})$ & $\begin{array}{c}\text { Plt } \\
\left(\times 10^{-14} / \mathrm{l}\right)\end{array}$ \\
\hline-2 & 6.88 & 4.86 & 4.41 & 134 & 179 \\
0 & 5.82 & 3.98 & 3.71 & 119 & 150 \\
+1 & 4.06 & 3.41 & 3.80 & 119 & 119 \\
+2 & $\mathbf{1 . 9 9}$ & $\mathbf{1 . 0 0}$ & 3.41 & 112 & 100 \\
+3 & 2.89 & 1.58 & 3.72 & 117 & 115 \\
+4 & 3.50 & 2.16 & 3.72 & 115 & 122 \\
+5 & 4.50 & 2.98 & 3.79 & 118 & 129 \\
+6 & 4.29 & 2.63 & 3.89 & 121 & 132 \\
+18 & 6.57 & 4.66 & 4.06 & 125 & 191 \\
\hline
\end{tabular}

The treatment with TSC of this patient highlighted two points: 1) There was no sign of any therapeutic effect after intravenous (not local, i.e. intratumoral) administration of the TSC. 6 days after the administration the metastatic process did not show any signs of regression. Moreover, after 40 days after the treatment there was a progression of the metastases. 2) After the intravenous administration the TSC are probably "homing" in the bone marrow despite the adipose tissue origin. Even a rather low cell count $\left(60 \cdot 10^{6}\right)$ was able to cause grade 2 (3) thrombopenia (neutropenia). It should be noted that this patient did not receive any systemic chemotherapy in the past. The observed bicytopenia with a nadir occurred $48 \mathrm{~h}$ after the administration of TSC (with concomitant prodrug administration). Therefore it should be carefully considered when a medical team decides to use the intravenous route.

\section{ACKNOWLEDGEMENT}

We are indebted prof. C. Altaner and his team from the Center for Cell Therapy and Regenerative Medicine for preparing the TSC.

\section{REFERENCE}

1. Kucerova L, Altanerova V, Matuskova M, et al. Adipose tissue-derived human mesenchymal stem cells mediated prodrug cancer gene therapy. Cancer Res 2007; 67: 6304-13. 